\title{
Eliminating Disharmony: Recent Examples of Censorship in Chinese Writing and Cinema
}

\section{Sebastian Veg}

\section{(2) OpenEdition}

12 Journals

Édition électronique

URL : http://journals.openedition.org/chinaperspectives/2043

DOI : 10.4000/chinaperspectives.2043

ISSN : 1996-4617

Éditeur

Centre d'étude français sur la Chine contemporaine

\section{Édition imprimée}

Date de publication : 15 septembre 2007

ISSN : 2070-3449

Référence électronique

Sebastian Veg, «Eliminating Disharmony: Recent Examples of Censorship in Chinese Writing and Cinema », China Perspectives [En ligne], 2007/3 | 2007, mis en ligne le 01 septembre 2010, consulté le 28 octobre 2019. URL : http://journals.openedition.org/chinaperspectives/2043; DOI : 10.4000/ chinaperspectives. 2043 


\title{
Eliminating Disharmony:
}

\author{
Recent Examples of Censorship in Chinese Writing and Cinema
}

SEBASTIAN VEG

This article examines contradictory recent trends in the Chinese censorship system regarding literature and cinema. While measures targeting the publishers of "eight banned books" in January 2007 demonstrated a preoccupation with the representation of history, fiction writing with political implications (Yan Lianke, Tsering Woeser) also remains sensitive. Independent cinema has recently been attempting to enter the official circuit, prompting the Film Bureau to accept a form of dialogue and negotiation with film directors. Nonetheless, the Bureau's continued preoccupation with a non-conflictual representation of society betrays the government's persisting tendency to assess films in terms of their political effects.

$\mathrm{C}$ ensorship in the Chinese press, including on the internet, is stringent and fairly straightforward, though never entirely predictable, and continually tested by Chinese journalists. An article, or series of articles will attract the censors' attention, the journalist will be fired or banned from reporting, and in extreme cases, the whole publication will be shut down, at least temporarily, as in the case of Bingdian (Freezing Point), the supplement to the Beijing Youth Daily in February 2006. Nonetheless, the complete closure of Strategy and Management in September 2004 (ostensibly because of an article attacking North Korea and China's leniency in dealing with Kim Jong-il), or of the China Development Brief in the Summer of 2007 came as surprises. ${ }^{(1)}$

In cinema and publishing, censorship is a more complex process. "Banned books" or "banned films" are usually situated somewhere on a wide spectrum ranging from pure underground existence (unapproved films sometimes available on pirate DVDs or books unpublished on the mainland but available over the internet or in pirate Hong Kong editions) to limited distribution, through a process which may involve cuts or other changes. When the Chinese government banned eight books in early 2007, several of them remained available in bookstores. ${ }^{(2)}$ One official apologetically explained that the ban was in fact not directed at the authors but at publishers who had not respected certain administrative regulations, and only forbade reprinting the listed books, not the sale of the first printing. Similarly some "banned films" are routinely available on pirate DVD, although they are not distributed through the official circuit and are not shown on state television.

Censorship in these areas lies mainly in the hands of two ministerial-level government organs placed directly under the control of the State Council, the General Administration of Press and Publications (GAPP) and the State Administration of Radio, Film and Television (SARFT). Both these organs are closely linked at the personnel and policy levels with the Central Propaganda Department (CPD), one of the five departments directly under the Central Committee of the Chinese Communist Party (CCP), headed by Politburo standing committee member Li Changchun, and which issues yearly guidelines on the subjects that should be avoided and the limits within which to deal with certain others. ${ }^{(3)}$ The complex bureaucratic procedure for approving a film involves the purchase of a quota-number from a state studio, submission of a script (or recently a 1,500-word synopsis), and the film itself. ${ }^{(4)}$ Books must similarly obtain an

1. For recent articles on censorship in the media see: He Qinglian, "Media censorship intensifies with continued crackdowns," HRIC Trends bulletins, 14 February 2007, http://hrichina.org/public/contents/article?revision $\% 5 \mathrm{fid}=36022 \&$ item $\% 5 \mathrm{fid}=32414$ (18/10/07); I. M. Sala, in "Chinese Journos dodge the Censors," Far Eastern Economic Review, October 2007, pp. 25-28, refers to a point system for the press, in which a "deficit of 12 points" entails closing down a publication; 6 points were allegedly taken from Sanlian News weekly for publishing a photo of Jiang Qing in April 2006; Thomas Scharping, "Administration, Censorship and Control in the Chinese Media: The State of the Art", China Aktuell, n 4/2007, pp. 96-118.

2. The author of this article saw a mainland edition of one of these books (Ruyan@sars.com) as late as 0ctober 2007 in Beijing.

3. The others are quoted by David Shambaugh as the United Front Work Dept., the International (Liaison) Dept., the Organization Dept. and the Central Discipline Inspection Commission. See D. Shambaugh, "China's Propaganda System, Institutions, Processes and Efficacy", The China Journal, ${ }^{\circ} 57$, January 2007, p. 34, and passim pp. 25-58. Anne-Marie Brady argues that the CPD also increasingly uses financial incentive to exert control in the media in "Guiding Hand: the Role of the CCP Central Propaganda Department in the Current Era", Westminster Papers in Communication and Culture, vol. 3, $\mathrm{n}^{\circ}$ 1, 2006, pp. 58-77.

4. See Valerie Jaffee, "Bringing the World to the Nation: Jia Zhangke and the Legitimation of Chinese Underground Film," Senses of Cinema, May 2004, http://www. sensesofcinema.com/contents/04/32/chinese underground film.html (18/10/07). 
ISBN number, which certain state publishers sell to smaller and more independent publishers willing to take the risk of a subsequent ban after publication. GAPP does not seem to enforce preventive control over books as SARFT does over films, probably because reading takes more time than watching a film, and it does not have the staff to deal with the over 50,000 books published every year. ${ }^{(5)}$ Films entering foreign film festivals must officially obtain prior approval, even when they have not gone through the previous procedure for distribution in China, but they may be approved for a foreign festival on the basis of a common understanding that they will be subsequently recut. For this reason, some observers believe that SARFT authorises more films to go to foreign festivals in order to demonstrate its openness, only to then ban these films for internal distribution. On the other hand, SARFT will crack down on films that participate in foreign festivals without authorisation. Independent documentary films (not funded by a state television channel) appeared only in the 1990s, and remain largely outside the system. ${ }^{(6)}$ Literary prizes tend to be less sensitive, but the reaction triggered by Gao Xingijan's Nobel prize is very similar to the case of films winning prizes at major festivals without prior authorisation (for example Jiang Wen's Devils at the Doorstep at Cannes in 2000, after which Jiang was banned from directing for five years). Gao Xingijan's novels and plays remain unpublished in mainland China even when they are, like Soul Mountain, largely devoid of political content. ${ }^{(7)}$ For all these reasons, censorship has become part of a strategic game between directors and, to a lesser degree writers, seeking spectators and funding, both at home and abroad, including through festivals or prizes, censors who attempt to control the "image of China" in films by independent directors (but are also anxious to limit the visibility of their interventions), and a foreign audience and investors quick to react to charges of censorship regardless of actual content. The government now mainly exerts pressure on directors through funding, which is also why fiction writers are less directly vulnerable to the state's intervention, as many of them hold academic positions that provide them with another source of income. To a certain extent, the state no longer needs to "ban" films as there is no funding outside the official circuit (except abroad for a very small number of directors) and bans actually create publicity for the film. This evolution does not mean, of course, that censorship is any more acceptable today than previously, it has simply developed into a complex game with many players, the outcome of which may depend on a number of factors, including but not limited to politics in the narrow sense.

\section{Historical and Political Problems}

Publications dealing with certain political questions, including modern history, insofar as it holds a political relevance today, are certain to attract the censors' attention, be they fiction or reportage. The guidelines issued by the CPD in its 2007 annual nationwide conference of heads of propaganda departments ${ }^{(8)}$ contain seventeen recommendations, of which twelve were leaked to the Hong Kong press: six out of these twelve were directly related to post-1949 history, including a ban on all publications regarding the anti-rightist movement and restrictions regarding the Cultural Revolution, any opinion not in accordance with the 1981 Resolution on Party history, writings on past and present government leaders, and memoirs of party leaders. ${ }^{(9)}$ Of the eight books targeted in early 2007 by GAPP, apparently acting on instructions of the CPD, five are directly related to historical events: Zhang Yihe's Past Stories of Peking Opera Stars, based on her academic research on Peking Opera, is related to persecutions during the Cultural Revolution; four other books (or series of books in one case) are memoirs or accounts of recent history, including Oblique Records of History. My Days at the Supplement Division of the People's Daily by veteran CCP member Yuan Ying, who was accused of leaking state secrets-an unlikely charge as the punishment in this case would have been much more severe. The memoir $C a n g$ Sang by Xiao Jian was criticised by Party elders for mentioning opium production in the CCP base in Yan'an. In the case of Zhang Yihe, GAPP did not highlight the content of the book but the author herself, whose two other books, which touched on her father Zhang Bojun-a prominent "rightist," had already been banned (Zhang Yihe

5. According to the Financial Times, 330 films were released in 2006 (Mure Dickie, "Chinese film maker sees moral angle," Financial Times, 20 0ctober 2007).

6. This has so far allowed Wang Bing, for example, to work in relative independence, entering his most recent film on the anti-rightist movement (He Fengming) for the 2007 Cannes Film Festival.

7. This ban seems to stem from Gao's political stance in 1989, when he was already residing in Europe and decided to renounce his Chinese citizenship and remain abroad. In his case, the "ban" seems to go somewhat further: his first plays, published in China in the 1980s, have disappeared from libraries; his name did not appear on a list of Nobel laureates for literature in a book on the Nobel Prize.

8. The Secretary-General of the CCP usually addresses these conferences. See D. Sham baugh, art. cit., p. 54 .

9. See Cheng Zhengde "Looking at future trends in the CCP through the 2007 CPD propaganda declaration", Dongxiang, March 2007, pp. 37-38. The other sensitive topics are "corrupt lifestyles," anti-Japanese feeling, foreign affairs (this is what would justify the shutdown of Strategy and Management), borders of the PRC, the military and the "year of the pig." Similarly, electronic publication of historical material was singled out by GAPP for specific control in 2006. 
pointed out that The Past is not Like Smoke was simply left to be sold out and not reprinted while $A$ Gust of Wind Carries Away the Verses of the Ages was ordered by bookstores to be actively withdrawn from sale). ${ }^{(10)}$

Interestingly, both Zhang Yihe and Yuan Ying protested by writing open letters to GAPP director Long Xinmin ${ }^{(1)}$ and his deputy $\mathrm{Wu}_{\mathrm{u}}$ Shulin. There was uproar on the internet and various other writers publicly endorsed their protest. According to an article in the Singapore Lianhe Zaobao, GAPP denied having "banned" the books, of which at least some remained available, asserting that the publishing houses were simply "criticised" for violations ranging from "dealing in book registration numbers, abusing the "Eleventh Five-Year Plan Key Publishing Project,' failing to file with the authorities prior to publication, and publishing harmful content." (2) Wu Shulin personally visited Yuan Ying to explain that in fact only five of the books were singled out for criticism and had not been banned, but simply their publishers fined or punished in other ways. Regarding Yuan Ying's book, the verdict, copied by Yuan Ying, was as follows: "Since this book did not follow the procedure for filing with respect to major topics, the publisher was issued a warning notice and will not receive an increase in book titles for year 2007." ${ }^{(3)}$ This judgement is consistent with the regulations leaked from the Propaganda department, and reveals the GAPP's flexibility in enforcing regulations, relying on financial pressure to bluff publishers into self-censorship. Because of limited staff and increasing publications, the propaganda system therefore increasingly relies on this type of self-censorship by publishers, and encourages paranoia by randomly choosing in one case to accuse a publisher of "dealing in book registration numbers" although this is a current practise in the publication industry.

In any event, history remains a persistent problem, whether in factual accounts, memoirs or even in fictionalised form, as shown by Yan Lianke's novel Serve the People, which looks at the Cultural Revolution in terms of "sexual politics" (an officer's wife and a young soldier's passion is heightened by fetishist use of Maoist icons). In this case the ban was explicit: the issue of the literary journal Huacheng in which it was published in 2005 was recalled, and the novel formally banned from book publication on the mainland by the CPD (but widely circulated on the internet).

\section{Social Issues}

Yan Lianke's following book, The Dream of Ding Village (Ding zhuang meng), a fictional account of the AIDS scandal in Henan based on careful documentary research, was first published by Shanghai Wenyi in 2006, and subsequently banned from being printed, sold and advertised, a decision which the GAPP later denied it had taken. ${ }^{(14)}$ It remained unclear to what extent each of these three provisions was enforced. Yan Lianke, who remains an employee of the Beijing Writers' Association, gave several interviews to the foreign press, in which he states that he had exercised a form of self-censorship in the novel to ensure he could publish it, and had adopted fiction as a less dangerous form than a documentary account of his research. Just as in the case of Hu Fayun's Ruyan@sars.com, which also touches on the Sun Zhigang scandal (a student taken for a migrant worker was beaten to death by the Guangzhou police), major public health and social problems are not acceptable to the CPD, even as subjects of fictional works. It is nonetheless interesting to observe Yan's strategy of both dropping hints of censorship to the foreign press while remaining an employee of the Writers' association.

The clearest Rubicon of all is arguably writing related to ethnic identity that does not echo the government line of national unity. A tragic example is Uyghur author Nurmuhemmet Yasin (born in 1974, known in Chinese as Ya Sen), who was arrested and sentenced to ten years in prison in early 2005 after publishing the short story "The Wild Pigeon" in Kashgar Literature (simultaneously shut down) in 2004. ${ }^{(15)}$ Rumours of Yasin's death by torture in his Urumchi prison circulated in August 2007. ${ }^{(16)}$ His story is broadly

10. See for example, "Eight Books Banned in Crackdown on Dissent," South China Morning Post (SCMP), 19 January 2007; Jean-Philippe Béja, "Chine: la vie difficile des censeurs," Esprit, July 2007, pp. 67-74. Discussion and English translations of the books are available on www.zonaeuropa.com/archive.htm, entries from 20 January to 11 February 2007. The other three books are about human rights activist Yao Lifa who challenged rigged local elections of corrupt officials, and two fictional narratives, one about SARS (Ruyan@sars.com by Hu Fayun) and one about the corruption in China's media industry (The Press by Zhu Huaxiang). See also the feature in Yazhou Zhoukan, 4 February 2007, pp. 40-45.

11. Long Xinmin was made a knight in the Legion of honour by the French government on 3 April, which caused an outcry, especially after he was demoted later that month over the book ban and rumours of corruption in Haidian. See http://www.rsf.org/article.php3?id article=21905 (18/10/07)

12. See "Gapp: Books criticized but not banned," http://www.danwei.org/media regulation/ gapp books criticized but not 1.php (18/10/2007).

13. "Yuan Ying PK Wu Shulin", http://zonaeuropa.com/20070211_1.htm (18/10/2007). Former Nanfang Zhoumo editor Qian Gang highly praises Yuan Ying's book in "The Other Stories of History," http://zonaeuropa.com/20070205 1.htm (18/10/07).

14. Edward Cody, "Yan Lianke and the Art of Compromise," The Washington Post, 8 July 2007. See also Mary-Anne Toy, "A Pen for the People," The Australian, 28 July 2007.

15. See the translation of the story: http://www.rfa.org/english/uyghur/2005/06/27/ wild_pigeon/ (18/10/2007).

16. See http://www.hrichina.org/public/contents/press?revision $\% 5$ fid=44686\&item $\% 5 f i d$ $=44685(18 / 10 / 07)$ 

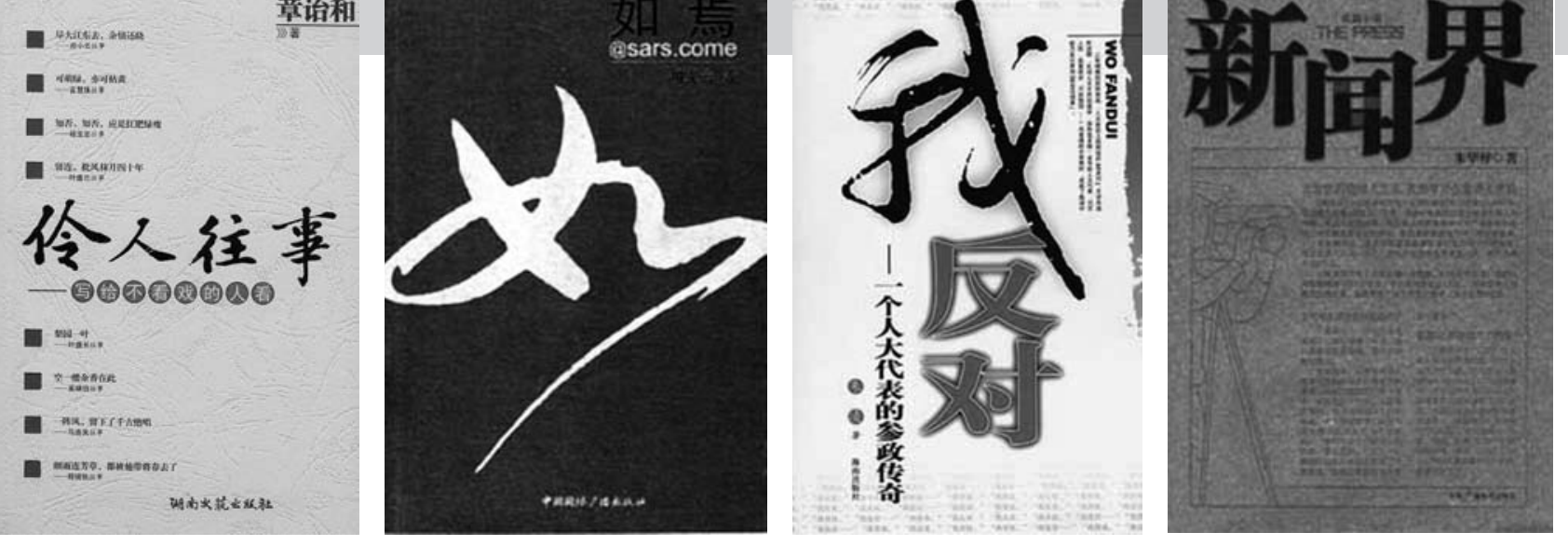

allegorical, describing the difference between wild and domesticated pigeons. While the latter no longer feel the urge to rebel against their masters, the wild pigeon which gives the story its name chooses death over life in a cage, to which he is confined by a younger human, against the advice of an elder man. Similarly, Tibetan author Tsering Woeser (known in Chinese as Wei Se), who like many Tibetans from Kham (Western Tibet, Sichuan province), including prize-winning author Alai, cannot read Tibetan and writes in Chinese, has published two books that are available in China only over the internet. Tibet Notes (Xizang Biji), a collection of travel and essayistic writing (sanwen) which contains much material on Tibetan Buddhism, was originally published by Guangzhou Huacheng Press in 2003, and went into a second printing before being charged by the CCP United Front Work Department with "serious political mistakes" and pulled from the shelves. After refusing to make changes and attack the Dalai Lama, Woeser was dismissed from the Tibet Autonomous Region Writers' Association in 2004, losing her salary, apartment and all status-related rights, and moved to Beijing. ${ }^{(17)}$ This is an example of how, at the other end of the spectrum, "censorship" can go well beyond pulling a book from the shelves of bookstores. Woeser's most recent work Forbidden Memory: Tibet During the Cultural Revolution (Shajie or Murder and Pillage), was published by Dakuai wenhua in Taipei in 2006: it is a collection of rare photographs of persecutions in Tibet taken by Woeser's father, and is not available on the mainland. Woeser's two blogs were shut down in July 2006 after she published a birthday poem to the Dalai Lama on one, but she seems to have begun operating another one recently. ${ }^{(18)}$

\section{Independent Cinema: Entering the system}

As shown by the public protest against the "eight books ban," censorship is no longer accepted as a given by audiences and readers in China. At the same time, writers and directors continue to strive for the particular public status bestowed by official publication by a mainland publisher or distribution through the official film circuit, notwithstanding the particular appeal held by the "banned" label, especially overseas. The censorship organs have also evolved, at least in their public discourse, in which they highlight the process of adapting and discussing aspects of the artistic works sub- mitted to them, rather than banning them outright, in order to ultimately achieve publication or distribution, which also benefits their public image, in China and abroad.

Jia Zhangke, in many ways the figurehead of the new generation of "independent cinema," decided in 2004 to put his new film The World through the procedure for obtaining official approval from SARFT and thus emerge from the underground, after encouraging signals had been sent by the administration that they were ready to "restore (his) credentials as a director." ${ }^{(19)} 2005$ marked the beginning of a thaw in SARFT policies: as of June 2006, initial approval could be granted on the basis of a 1,500-word synopsis and authority for approval was delegated to six (now seven) regional Film offices. ${ }^{(20)} \mathrm{A}$ dialogue with underground directors was thus initiated, which to an extent is still ongoing today. As a result, The World was distributed in China, as was also Jia's latest film Still Life (2006), which he deliberately scheduled to open at the same time as Zhang Yimou's commercial hit Curse of the Golden Flower.

Aspiring to a "long march through the institutions" is common among independent filmmakers, as shown also by Zhang Yuan's move from underground to official distribution with Seventeen Years (1999) or Lou Ye's Purple Butterfly (2003), which was selected for the Cannes Festival as an "official" film, and drew harsh (if not entirely undeserved) criticism (Lou Ye had been previously banned from making films for two years after Suzhou River in 2000). Nonetheless, his latest film, Summer Palace, was predictably banned for distribution in China, although the synopsis had been originally approved. After the film was shown in Cannes in 2006 despite criticism of "technical failings," SARFT de-

17. See Wang Lixiong, "Tibet facing Cultural Imperialism of Two Kinds: An Analysis of the Woeser incident," http://www.phayul.com/news/article.aspx?id=8619\&t=1\&c=4 (18/10/2007). English translations of some of Woeser's writings have been published in the China Rights Forum, notably in issue 2006/4.

18. Paul Mooney, "Unfree Thinker," SCMP, 3 January 2007.

19. See V. Jaffee, "Bringing the World to the nation," art. cit. Jia's disgrace in the eyes of SARFT seems to date back to his first feature film Xiao Wu (1999): Jia wrote an article recounting his first meeting with SARFT and hinting that he had been denounced by a colleague. See "A record of confusion", http://www.danwei.org/film/iia zhangke vs zhang yimou.php (18/10/07). Tensions have continued after the producer of Zhang Yimou's latest film suggested that the Golden Lion award for Still Life at the 2006 Venice Festival had been fixed.

20. See also Liu Wei: "Censoring Movies done according to script" (interview with Zhang Hongsen), China Daily, 31 August 2007, p. 14. A full script continues to be required for "significant revolutionary or historic subjects, religion, diplomacy, minors or judicial system." 


\section{cided to ban it entirely and bar Lou Ye from making films} for five more years. The issues at stake were not so much the sex scenes as the veiled allusions to the student movement of 1989: the film effectively portrays how the failure of the initial student protests (no political slogans appear and no mention is made of Tiananmen square or the repression) somehow breaks the resolution of an entire generation, with the main characters drifting aimlessly around China and, in one case, Europe, for the rest of the film, failing to find a justification for continuing to live their lives.

Other films have been approved, despite taking up sensitive subjects. Li Yang's latest film Blind Mountain (2007) is a scathing indictment of the continuing practice of trafficking women, who are sold into marriage in remote mountain villages, where they are raped until they become pregnant and lose the will to escape. It is true that, in the final scene of the film, the police intervenes on the side of law and order (and proves powerless, at least temporarily). Nonetheless, despite the approximately twenty cuts requested by the censors before approving it for distribution, the film contains much moral criticism of contemporary Chinese society and the role of local cadres in protecting criminals that has in other cases proven unpalatable to censorship authorities.

\section{Banned Films and Social Harmony}

Reversely, two films dealing with seemingly less sensitive issues were ultimately banned from distribution in 2007 (or at least de facto not distributed), despite repeated cuts at the request of SARFT. Thirteen Princess Trees (Shisan ke paotong) by Lü Yue, based on a novella by He Dacao titled Knife and Knife (Daozi he daozi), revolving around a group of high-school students in Chengdu, was recut five or six times, and edited in sixteen places, according to the director. ${ }^{(21)}$ In this process, various scenes involving the teenagers' sexuality, including contact between a teacher and a student, were excised; nonetheless, the film was not authorised for distribution. By telling the story of a girl in her last year of high school who is more interested in the boys in her class than her grades at the gaokao (university entrance exam), finally falls for an obese and more experienced member of the class, and briefly runs away from home, the film addresses issues that were deemed unacceptable. Family violence, in particular the casting of the main character's father as an alcoholic policeman, was certainly also a factor. The film had already passed several inspections and won a prize at the 2006 Tokyo Film Festival when its release was blocked just days before it was scheduled to open in China on 23 March 2007, officially for technical reasons (it had to be converted from DV to film for the official distribution circuit). As of early November 2007, it is now rumoured to be approved for release.

A similar fate befell Lost in Beijing (Pingguo) by Li Yu, which tells the story of a migrant woman working in a "private club" in Beijing (her name is Pingguo, which became the film's title in China after SARFT refused that the word Beijing appear in it). After she is raped by her Cantonese boss (Tony Leung Ka-fai), her husband blackmails him, convincing his wife to keep the baby, and even bribes the doctor to change its blood group on the birth certificate in order to extort yet more money from the boss. The film was rejected by the rating committee shortly before the Berlin Festival in February 2007, then approved after around fifteen minutes were cut, mainly depictions of Beijing that were deemed unworthy of an Olympic city (dark alleys, prostitutes, contrasting with Tiananmen square) and a whole part of the story narrating an affair between the boss's wife and Pingguo's husband. There seems to have been no final decision on the release of the film in China at this point. Such contradictory signs prompted Jia Zhangke to go so far as to doubt the existence of real political principle in the censors' minds: "We don't have a real censorship system. Whether a film can be passed or not randomly relies on people rather than a system." (22) Many Chinese artists now tend to equate government censorship with "censorship by the market" and commercial interests.

21. "What's wrong with Thirteen Princess Trees?," http://www.danwei.org/film/ whats_wrong_with_thirteen_prin.php (18/10/07). Lü Yue, born in 1957, attended the class of 1978 at Beijing Film Institute, and was later Zhang Yimou's cinematographer.

22. He made this remark at a panel on censorship at the Berlin film festival in February 2007. See http://www.berlinale-talentcampus.de/story/13/2013.html (19/10/2007). 
$\pi$

$\geq \quad$ among which are social harmony and a form of national pride. This appears to be a kind of "sediment," left by the more stringent campaigns of bygone days.

This trend has been equally apparent in recent discussions on school textbooks, particularly in literature and history. Only in very recent years have curricula begun to de-emphasise ideological aspects in these two subjects, sometimes meeting with strong resistance. Tellingly, it was the criticism of history manuals on a seemingly obscure point of detail by Sun Yat-sen university professor Yuan Weishi which caused the closure of Bingdian in 2006 (he argued that continuing to teach that the Boxers were spontaneous patriotic rebels against foreign imperialism rather than violent militias manipulated by the Qing court was absurd in the present age). The 2007 experimental reform in Beijing municipality literature textbooks also seems destined to cautiously broaden the spectre of works that can be taught within the curriculum (increasing the number of modern foreign works), but balancing the excision of "red classics" with the inclusion of works infused with traditional morals, like Louis Cha (Jin Yong)'s martial arts novels. ${ }^{(27)}$ Therefore, on the one hand, certain issues of history and politics remain very clearly off limits (post-1949 and CCP history, social and ethnic conflicts, health crises). But even the areas in which more tolerance has been introduced are subject to an unchangingly moralising and instrumental logic, in which artistic creations are assessed not on their own merit, but as vectors for sets of values that the state chooses to endorse or not. ${ }^{(28)} \mathrm{At}$ the same time, absolute censorship has become a technical impossibility, and many "bans" are simply ways of reserving access to certain works to an elite or a "small circle." Most importantly, the strategic interaction between various players in the field, and the challenge this interaction represents to artists, has stimulated a new generation of writers and directors whose work never ceases to pose new challenges to the system.
27. Much discussion was devoted to the exclusion of famous texts by Lu Xun from the curriculum, including "In Memory of Ms Liu Hezhen" and "The True story of Ah Q," but it should be remembered that these texts are routinely taught in a purely ideological way in Chinese high schools. See also Li Datong, "Shanghai: new history, old politics," Open Democracy, 19 September 2007, http://opendemocracy.net/node/34582 (19/10/2007).

28. Contemporary art is probably an exception to this statement (the State chooses to tolerate its existence, almost regardless of content), but only insofar as it is created and commercialised entirely outside of State circuits, relying exclusively on funding by the international market. 